\title{
PENGEMBANGAN KETERAMPILAN MANAJERIAL USAHA MELALUI PENYUSUNAN LAPORAN KEUANGAN BADAN USAHA MILIK DESA
}

\author{
lid Mufaidah'), Azwar Annas'), Adinda Sukmaningati'1), Nur Hidayatun Ni'mah Alfia Nisa1)
}

1)Program Studi Agribisnis, Institut Teknologi dan Bisnis Muhammadiyah Banyuwangi, Jawa Timur, Indonesia 68465

JL. KH. Wachid Hasyim No.60 Genteng Banyuwangi

E-mail: iid.mufaidah@itbmb.ac.id

\section{Diterima 09 Juli 2021, Direvisi 30 Juli 2021, Disetujui 31 Juli 2021}

\begin{abstract}
ABSTRAK
Kegiatan pengabdian kepada masyarakat ini bertujuan untuk memberikan pengetahuan dan kemampuan terhadap badan Usaha Milik Desa (BUMDES) dalam rangka meningkatkan akuntabilitas dan transparansi keuangan. Permasalahan utama yang terjadi selama ini pada BUMDES adalah keterbatasan dalam hal manajerial usaha berupa penyusunan laporan keuangan. Hal tersebut mengakibatkan usaha tidak bisa berkembang dengan baik, karena ketidakmampuan penyusunan laporan keuangan yang menjadi syarat dalam memperoleh modal dari pihak bank atau lembaga keuangan lainnya. Selain itu, kesulitan memperoleh kepercayaan masyarakat terhadap kegiatan usaha yang dilakukan. Metode yang dikembangkan dalam kegiatan ini terdiri dari enam tahapan yaitu observasi, pemberian materi, pelatihan, pendampingan dan evaluasi. Hasil dari kegiatan ini adalah kemampuan setiap anggota dalam menyusun laporan keuangan melalui menajemen pembukuan secara sederhana yaitu berupa jurnal transaksi keuangan, buku besar, laporan laba rugi dan neraca keuangan.
\end{abstract}

Kata kunci: manajerial; laporan keuangan; BUMDES; akuntabilitas.

\begin{abstract}
This community service activity aims to provide knowledge and capabilities to Badan Usaha Milik Desa (BUMDES) in order to improve financial accountability and transparency. The main problem that has occurred in BUMDES is the limitation in terms of business management in the form of preparing financial statements. This resulted in the business not being able to develop properly, due to the inability to prepare financial statements which were a requirement in obtaining capital from banks or other financial institutions. In addition, it is difficult to gain public trust in the business activities carried out. The method developed in this activity consists of six stages namely observation, presentation, training, mentoring and evaluation. The result of this activity is the ability of each member to compile financial reports through simple bookkeeping management in the form of financial transaction journals, ledgers, income statements and balance sheets.
\end{abstract}

Keywords: managerial; financial statements; BUMDES; accountability

\section{PENDAHULUAN}

Desa menjadi salah satu tempat yang potensial dalam perekonomian suatu negara. Badan Usaha Milik Desa (BUMDES) yang merupakan suatu usaha lembaga desa yang dikelola oleh pemerintah desa denan tujuan untuk memperkuat perekonomian di desa dan dibentuk berdasarkan kebutuhan dan potensi desa yang bersangkutan. BUMDES yang seluruh atau sebagian modalnya berasal dari desa melalui penyertaan modal langsung dari kekayaan desa yang dipisahkan untuk mengelola aset, jasa pelayanan dan usaha lainnya untuk meningkatkan kesejateraan masyarakat (Mahmudah, 2018; Titioka, 2020)

Hal ini lah yang menjadikan BUMDES harus selalu melakukan pengelolaan keuangan, penataan dan pengembangan usaha untuk memperoleh keuntungan yang nantinya berujung pada peningkatan kesejahteraan masyarakat. Untuk mengetahui besaran keuntungan yang didapatkan untuk setiap unit usaha maka anggota BUMDES terutama bendahara harus memiliki wawasan tentang kemampuan manajerial usaha yaitu pembukuan sederhana. Pembukuan sederhana pada akhirnya akan menghasilkan laporan keuangan berupa laporan laba rugi, dan neraca keuangan setiap periodenya (Istanti, Agustina, Wijijayanti, \& Dharma, 2020).

Kemampuan yang kurang baik dalam penyusunan laporan keuangan inilah yang menjadi keterbatasan bagi BUMDES sehingga kesulitan akses untuk memperoleh modal dari 
pihak ketiga yaitu bank maupun lembaga keuangan lainnya, kesulitan dalam penyetoran pajak karena serta kurangnya kepercayaan publik terhadap akuntabilitas dan transparansi badan usaha. Hal tersebut di atas menjadi permasalahan yang sering dihadapi oleh BUMDES Lembu Suro, Desa Genteng Kulon, Kecamatan Genteng, Kabupaten Banyuwangi.

Berdasarkan beberapa keterbatasan dan kesulitan yang dihadapi oleh BUMDES, maka melalui kegiatan pengabdian kepada masyarakat ini dapat memberikan solusi melalui pelatihan dan pendampingan proses pembuatan laporan keuangan yang baik dan benar. Sebagaimana tujuan dari kegiatan pengabdian ini adalah yaitu memberikan wawasan tentang pentingnya laporan keuangan bagi badan usaha, meningkatkan keterampilan dan kemampuan setiap anggota BUMDES dalam membuat rangkaian laporan keuangan antara lain berupa jurnal transaksi keuangan, buku besar, laporan laba rugi dan neraca keuangan.

\section{METODE}

Pelaksanaan kegiatan pengabdian kepada masyarakat dilakukan pada tanggal 6 April sampai dengan 10 Mei 2021 di Kantor desa dan BUMDES Lembu Suro Genteng Kulon, JI KH. Wachid Hasyim Lapak no. 6 RTH Maron-Genteng, Banyuwangi dengan jumlah peserta sebanyak 20 orang. Metode pelaksaanya melalui beberapa tahapan sebagai berikut: 1) Observasi pendahuluan, kegiatan ini dilakukan dengan melakukan pengamatan terhadap kinerja keuangan BUMDES, diikuti dengan wawancara maupun diskusi dengan kepala desa dan seluruh struktural BUMDES, untuk mengetahui apa saja yang dibutuhkan sehingga tahap kegiatan selanjutnya menjadi sinkron antara kebutuhan dengan isi pelatihan dan pendampingan. 2) Penyampaian Materi pentingnya laporan keuangan terhadap kemajuan usaha. 3) Pemberian contoh kasus laporan keuangan berbagai macam usaha dan penyelesaiaannya. 4) Pelatihan pencatatan transaksi keuangan, posting jurnal umum dan buku besar (General ledger), pembuatan laporan laba/ Rugi dan Neraca. 5) Kegiatan Pendampingan dalam pencatatan Laporan keuangan, mulai dari penyelesaiaan periode pertahun (tutup buku) sampai dengan buka buku untuk awal periode tahun 2021. 6) Evaluasi dari hasil pelatihan dan pendampingan dengan melihat kesesuaian antara tujuan kegiatan dengan hasil telah diperoleh.

\section{HASIL DAN PEMBAHASAN}

Kegiatan Pengabdian Kepada
Masyarakat melalui pelatihan dan
pendampingan penyusunan laporan keuangan
dengan beberapa tahap pelaksanaan:

\section{1) Observasi Pendahuluan}

Kegiatan awal yang dilakukan adalah pengamatan terhadap usaha yang BUMDES yaitu meliputi tanya jawab seputar jumlah jenis unit usaha yang dijalankan, keuntungan atau kerugian yang diperoleh setiap bulannya, sistem pencatatan keuangan selama dilakukan, oleh siapa dan untuk siapa laporan keuangan dipertanggungjawabkan, siapa saja yang berkepentingan dalam usaha tersebut dan sampai dengan pemetaan latar belakang pendidikan anggota BUMDES. Wawancara dilakukan kepada kepala desa selaku komisaris BUMDES, manager dan anggota BUMDES sebagai mana terlihat pada (Gambar 1). Hal tersebut dilakukan agar penyampaian materi, pelatihan dan pendampingan dapat efektif.

Unit usaha yang dilakukan BUMDES adalah unit usaha jasa pelayanan yaitu sewa lapak dagang, tempat bermain anak, jasa parkir dan lainnya. Beberapa unit usaha yang dijalankan memiliki berbagai macam permasalahan dalam hal laporan keuangan, berikut permasalahan dalam pelaporan keuangan di BUMDES antara lain:

a) Bendahara dan sekretaris kesulitan dalam memahami pencatatan keuangan dan cenderung enggan melakukan pencatatan terbukti beberapa transaksi lupa untuk dicatat dan hanya pengumpulkan bukti transaksi saja,

b) Adanya kompleksitas dalam penyusunan laporan keuangan sehingga enggan melakukannya secara sistematis sebagaimana contoh beberapa BUMDES di Indonesia hanya mencatat uang masuk dan keluar secra sederhana saja (Amin \& Astuti, 2021).

c) Pembukuan yang lengkap dan sistematis membutuhkan waktu dalam penyusunanya sedangkan masing-masing anggota juga merangkap profesi kerja sehingga tidak ada waktu. Berikut Gambar Kegiatan observasi pada bumdes Lembu suro. 


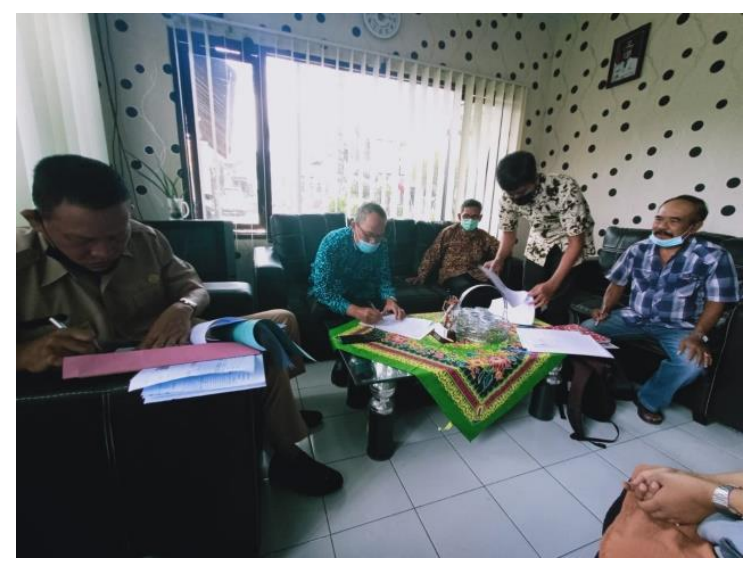

Gambar 1. Kegiatan Observasi awal kebutuhan pelatihan.

\section{2) Penyampaian materi pentingnya laporan keuangan terhadap kemajuan usaha.}

Setelah pengamatan dilakukan, maka selanjutnya adalah diskusi dengan semua yang terlibat di dalam BUMDES, sehingga dalam penyampaian materi sinkron dengan kebutuhan saat ini yaitu materi tentang pentingnya laporan keuangan terhadap kemajuan usaha, proses penyampaian materi terlihat pada (Gambar 2). Hal tersebut dilakukan karena laporan keuangan menjadi salah satu yang sangat berpengaruh dalam menganalisis kemampuan sebuah usaha untuk menyelesaikan permasalahan keuangan dan pengambilan keputusan (Herawati, 2019; Irawati \& Martanti, 2017; Rabuisa, Runtu, \& Wokas, 2018)

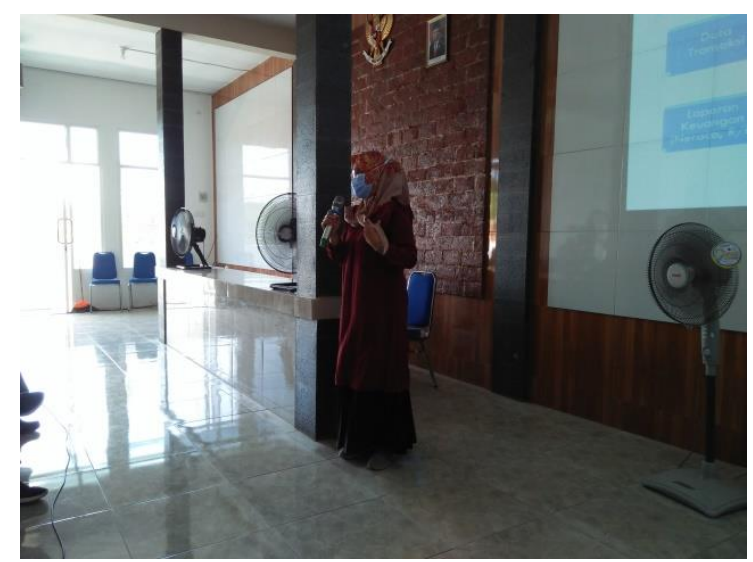

Gambar 2. Penyampaian Materi Pentingnya Penyusunan Laporan Keuangan terhadap Kemajuan Usaha.

Keuntungan besar dalam pembuatan laporan keuangan adalah kemudahan bagi pihak lain untuk membaca kondisi keuangan BUMDES sehingga usaha tersebut untuk akan lebih mudah menarik kreditur untuk memberikan akses modal baik itu dari pihak Bank maupun dari lembaga keuangan lainnya. Penyampaian materi mendapatkan antusiasme peseta acara seperti terlihat pada (Gambar 3).

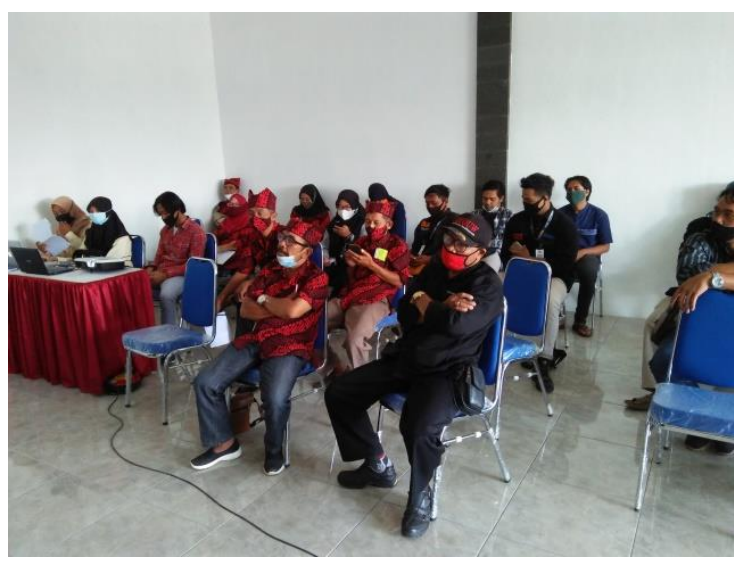

Gambar 3. Antusiame Peserta Kegiatan Materi Pentingnya Penyusunan Laporan Keuangan BUMDES.

\section{3) Pemberian contoh kasus laporan keuangan}

Walaupun jenis usaha yang dilakukan oleh BUMDES adalah jenis usaha jasa, dalam hal ini tentu pemberian contoh laporan keuangan adalah laporan keuangan untuk perusahaan jasa, namun contoh laporan keuangan untuk usaha dagang dan usaha manufaktur juga diberikan. Terlihat pada (Gambar 4) pada dasarnya tujuannya adalah memberikan stimulus kepada seluruh anggota bahwa rangkaian kegiatan untuk menghasilkan laporan keuangan yang baik itu sebenarnya mudah untuk dilakukan apabila proses pencatatan dan mendapatkan dukungan semua pihak untuk berkembang.

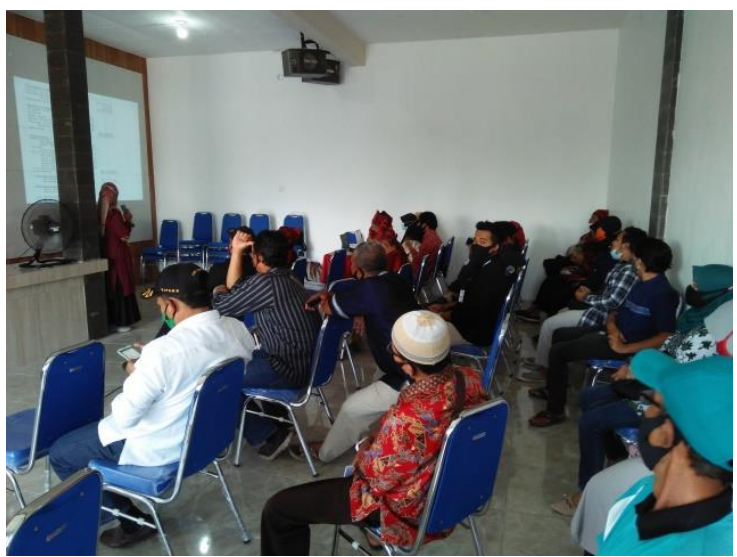

Gambar 4. Kegiatan pemberian contoh kasus laporan keuangan.

\section{4) Pelatihan Pencatatan}

Satu persatu anggota diberi pelatihan tentang pencatatan transaksi keuangan yang tampak pada (Gambar 5). Pertama kali yang harus difahami oleh peserta pelatihan adalah mengenal dan membedakan akun-akun dalam akuntansi. Kategori aset: aktiva lancar dan aktiva tetap, pendapatan, pengeluaran beban, 
pajak, kewajiban (hutang), modal dan penarikan modal. Setelah itu peserta pelatihan mulai mengelompokkan akun- akun tersebut, dan mengorganisir tanda bukti pemasukan maupun pengeluaran, surat berharga perusahaan, baru kemudian dilakukan pencatatan setiap transaksinya. Pencatatan transaksi pertanggal kejadian transaksi ke dalam jurnal umum, masing masing akun akan diposting kedalam buku besar. Dari buku besar bisa dibuat laporan laba rugi yaitu dengan memasukkan seluruh akun pemasukan, pengeluaran, serta pajak. untuk laporan neraca diperoleh dari pencatatan akun buku besar berupa aset (aktiva), pasiva dan modal usaha.

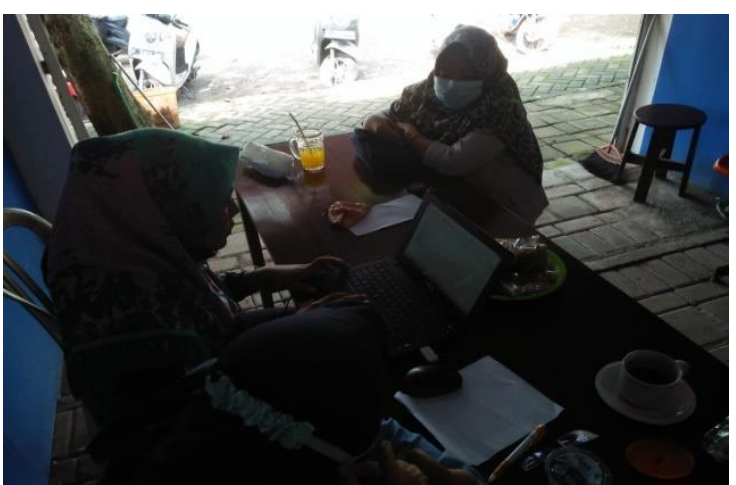

Gambar 5. Kegiatan pelatihan pencatatan transaksi keuangan.

\section{5) Kegiatan Pendampingan}

Kegiatan selanjutnya dari PKM ini adalah melakukan pendampingan terhadap anggota BUMDES yang menyelesaikan laporan keuangan BUMDES terlihat pada (Gambar 6). Penyelesaian penyusunan laporan keuangan tahun 2020 dan laporan keuangan akhir periode maret tahun 2021. Bendahara, sekretaris dan anggota dalam struktural BUMDES melakukan pembagian tugas untuk menghasilkan laporan keuangan yang akuntabel dan transparan yaitu pencatatan transaksi harian dan mingguan sehingga tidak ada transaksi yang lupa dibukukan. Langkah selanjutnya adalah menyamakan persepsi tentang nama-nama akun yang akan dicatat agar tidak terjadi kesalahan atau pecatatan ganda, penyusunan laporan keuangan (jurnal umum, buku besar, laporan laba rugi dan neraca) dilakukan oleh sekretaris dan bendahara kemudian dianalisis oleh manajer dan Komisaris BUMDES. Laporan keuangan inilah yang akan siap dilaporkan serta diaudit oleh audit internal pemerintah desa maupun auditor eksternal. Berikut Gambar Kegiatan pendampingan yang dilakukan terhadap seluruh anggota BUMDES.

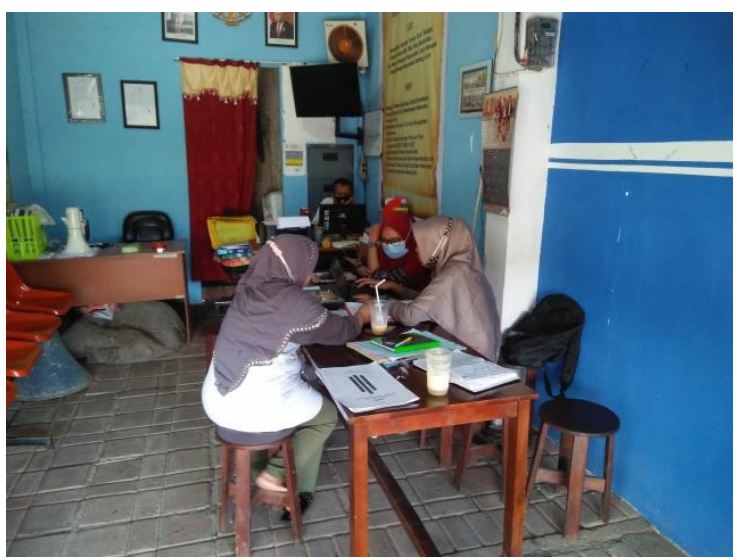

Gambar 6. Pendampingan penyusunan laporan Keuangan BUMDES 2021.

\section{6) Evaluasi}

Kegiatan akhir dari pengabdian Kepada masyarakat ini adalah evaluasi. Berdasarkan pengamatan setelah melalui rangkaian kegiatan pengabdian masyarakat adalah semua anggota BUMDES telah memilki wawasan terhadap pentingnya laporan keuangan terhadap badan usaha dan memiliki keterampilan dengan menunjukkan hasil dari pelatihan dan pendampingan berupa jurnal keuangan, buku besar, neraca keuangan dan laporan laba rugi.

\section{SIMPULAN DAN SARAN}

Kegiatan Pengabdian kepada masyarakat ini dapat diambil kesimpulan bahwa seluruh anggota BUMDES telah memiliki wawasan tentang pentingnya laporan keuangan bagi badan usaha, meningkatnya keterampilan dan kemampuan setiap anggota BUMDES dalam membuat jurnal transaksi keuangan, buku besar, laporan laba rugi dan neraca keuangan. Hal ini berdampak positif bagi perkembangan BUMDES dalam meningkatkan usaha dan menanamkan kepercayaan bagi kreditur serta masyarakat tentang kondisi keuangan perusahaan secara riil, akuntabel dan transparan.

Sebagai tindak lanjut dari kegiatan ini adalah sebaiknya pelatihan dan pendampingan manajerial usaha dilakukan secara periodik dengan topik permasalahan BUMDES yang lainnya.

\section{UCAPAN TERIMAKASIH}

Ucapan terimakasih ditujukan kepada Institut Teknologi dan Bisnis Muhammadiyah Banyuwangi dan Kepala Desa Genteng Kulon sekaligus sebagai Komisaris BUMDES, atas terselenggaranya pelatihan dan pendampingan kepada seluruh anggota BUMDES dalam pengembangan keterampilan manajerial usaha. 


\section{DAFTAR RUJUKAN}

Amin, A., \& Astuti, N. P. (2021). Akuntansi Bumdes Di Desa Je'Nemadinging Kabupaten Gowa. Jurnal Komunitas: Jurnal Pengabdian Kepada Masyarakat, $3(2)$, 137-142. https://doi.org/10.31334/jks.v3i2.1276

Herawati, H. (2019). Jurnal Akuntansi Unihaz JAZ JUNI Jurnal Akuntansi Unihaz - JAZ JUNI. Jurnal Akuntansi Unihaz, 2(1), 1625. Retrieved from https://journals.unihaz.ac.id/index.php/jaz /article/view/1333

Irawati, D., \& Martanti, D. E. (2017). Transparasi Pengelolaan Laporan Keuangan BUMDes terhadap Pelaporan Aset Desa (Studi Fenomenologi Pada BUMDes Desa Karangbendo Kec Ponggok Kab Blitar). Prosiding Seminar Nasional Dan Call For Paper Ekonomi Dan Bisnis, 2017, 41-51.

Istanti, L. N., Agustina, Y., Wijijayanti, T., \& Dharma, B. A. (2020). Pentingnya Penyusunan Laporan Keuangan UMKM Bagi Para Pengusaha Bakery, Cake and Pastry ( BCP ) di Kota Blitar. Jurnal Graha Pengabdian, 2(2), 163-171.

Mahmudah, S. (2018). Akuntabilitas laporan keuangan badan usaha milik desa (studi kasus: bumdes desa sungon legowo bungah gresik). Ecopreneur Fakultas Ekonomi, 1(2), 52-56.

Rabuisa, W. F., Runtu, T., \& Wokas, H. R. N. (2018). Analisis Laporan Keuangan Dalam Menilai Kinerja Keuangan Perusahaan Pada Bank Perkreditan Rakyat (Bpr) Dana Raya Manado. Going Concern : Jurnal Riset Akuntansi, 13(02), 325-333.

https://doi.org/10.32400/gc.13.02.19518. 2018

Titioka, B. M. (2020). Pengelolaan Keuangan BUMDES di Kabupaten Kepulauan Aru. Jurnal Pengabdian Masyarakat Jamak (Manajemen \&Akuntansi) Vol 03. No. 01, Juni 2020, 03(01), 1-9. 